\title{
A Conceptual Model of Technology Transfer for Public Universities in Mexico
}

\author{
Hugo Necoechea-Mondragón', Daniel Pineda-Domínguez ${ }^{2}$, Rocío Soto-Flores
}

\begin{abstract}
Technology transfer from academic and scientific institutions has been transformed into a strategic variable for companies and nations who wish to cope with the challenges of a global economy. Since the early 1970s, many technology transfer models have tried to introduce key factors in the process. Previous studies have shown that technology transfer is influenced by various elements. This study is based on a review of two recent technology transfer models that we have used as basic concepts for developing our own conceptual model. Researcher-firm networks have been considered as key elements in the technology transfer process between public universities and firms. The conceptual model proposed could be useful to improve the efficiency of existing technology transfer mechanisms.
\end{abstract}

Keywords: technology transfer, universities, researchers, networks, models, researcher-firm networks

\footnotetext{
'Coordinación de Operación de Redes de Investigación y Posgrado, Secretaría de Investigación y Posgrado del Instituto Politécnico Nacional .Edificio de la Secretaria Académica,Avenida Miguel Othón de Mendizábal s/n, 07738 Ciudad de México, México.

E-mail: hnecoecheam@ipn.mx;Tel: +52 5557296000 ext. 5065I.

${ }^{2,3}$ Profesor -Investigador de la E.S.C.A. Santo Tomás del Instituto Politécnico Nacional. Carpio 47I, Col.

Plutarco Elías Calles. CP. I I340, Ciudad de México, México.
} 


\section{Introduction}

In our present economic environment, the ability to translate research funding into products and services through technology transfer (TT) is critically important. Analyzing and understanding how to manage TT from academic and scientific institutions into marketable ideas is currently one of the most important topics in social sciences academic research. The papers in this issue attempt to consider the broader impact of universities as actors in economic and industrial development. They provide a more critical assessment of the factors, environments and conditions that affect the ability of universities to promote socially desirable outcomes. In the present century, universities are being evaluated by their ability to patent and license technology, and to spin out firms based on university research. This new focus has shifted attention away from the main roles of the university as teaching, research and knowledge generating institutions. Many current studies of economic growth emphasize the role of universities and other institutions of higher education, and have found an increasing focus on TT (Heysey and Adelman, 20I I).

Many firms are being attracted to the very specific activities and skills that only exist in some regions and locations (Audretsch et al., 20/2). These activities and skills may be linked to scientific or academic institutions that have changed their mission and vision towards a more entrepreneurial orientation. The academic entrepreneurship orientation, the quantity and quality of social networks, and the experience of industrial collaboration will increase with time and play an important role in knowledge transfer and TT (Siegel and van Pottelsberghe de la Potterie, 2003; Siegel, et al., 2003).

Considering the difficulties and complexities faced by managers of TT projects, researchers, consultants, and practitioners of technology transfer, many different authors have presented TT models that are oriented to improve the planning and implementation of TT projects (Sazali et al., 2009; Singh and Aggarwal, 2010). In this century, many Mexican enterprises are unable to compete in the global market without efficient knowledge absorption. Today's situation require a considerable increase in the quality of TT management and a clear TT model that is tailored to the needs of Mexican universities, researchers and firms. The Mexican government should come out with a clear policy statement to reinforce the importance of technology generation and transfer, patents, and the researchers' ownership of intellectual property as well as the importance of researchers as a means to boost the limited relations between the scientific and industrial environments.

It is currently clear that the limited investment made by Mexican firms in research and development (R\&D) and knowledge and technology transfer through the purchase of capital goods and technology products is able to solve problems in the short term. To a lesser degree, this includes their investment in new processes and products know-how and scientific knowledge (Feria and Hidalgo, 20l I).

Global innovation networks are emerging as a result of the international division of the innovation processes through (among others) international technological collaborations (Prato and Nepelski, 20I2). Innovation networks are connecting industry, academic institutions, and public and nonprofit organizations with a global network of research scientists to manage intellectual property and provide innovative solutions to challenging problems (Heisey and Adelman, 20II).

The aim of this study is to develop a model describing the importance of the researcher-firm networks for public universities in Mexico based on a review of two TT models used as basic concepts for developing our own model of TT that is tailored to the needs of Mexican universities, researchers, firms and government current situation.

\section{Background}

\section{I The role of universities in the new economy}

Knowledge as a key element for the economic development of modern economies has for a long time been replaced by the concept of capital and labor as the main players in the economy (Eckl, 20I2). However, the regions that will flourish in the globalized and knowledge-based economy of the 2 Ist century will be those with the greatest knowledge assets (Goldstein and Glaser, 20I2). Globalization generates competition worldwide, forcing many governments to adopt market-oriented policies. Competition stimulates firms to continually innovate, improve quality and reduce the cost of existing products. At the same time, companies can no longer acquire or afford all of the technological and human resources that they need. This inhibits their ability to encourage flexible relationships with other firms and (most importantly) institutions such as universities (Audretsch et al., 2012). The result of globalization has been an increasing trend in research over the last 25 years towards involving technology and knowledge transfers from academic institutions to private industry (Siegel et al., 2003).

Since the beginning of nineteenth century, universities have had a double role of performing both higher education and research activities. However, in the last decades of the 20th century, universities also started to be regarded as providers of knowledge that is useful for exploitation in practical terms. The increasing interest for the relations existing between knowledge production in universities, industrial 
innovation and economic growth has initiated significant changes in the traditional structure of many higher education institutions. This has strongly established relations in the framework that are commonly termed as the third mission. Consequently, the transfer of knowledge or technology outside universities, and the role played by them in this transfer, are nowadays considered as critical elements and are being performed in a formally organized way (Rolfo and Finardi, 20I2).

The conversion of university research into economic growth is vital for the future of many nations, especially in nations in the developing world (Warren et al., 2008). Universities play a unique role in society, providing a group of experts in experimentation and innovation. Even so, leaders around the world have had to push for the primacy of universities to retain national competitiveness in the global economy (Breznitz and Feldman, 20I2). Some universities have been criticized for being more adept at developing new technologies than moving them into private sector applications. In a similar vein, policymakers have often maintained that the long lag between the discovery of new knowledge at the university and its use by firms could seriously impact the global competitiveness of a country (Siegel et al., 2004).

Currently, the universities in some countries contribute to healthy and sustainable regional economies in numerous ways. There is a so-called 'milieu', or co-location effect, which happens because universities create significant positive economic development effects by attracting scientists, engineers, and entrepreneurs to locate in geographical regions where there is a concentration of highly educated and creative people teaching and conducting research who are employed by the university (Goldstein and Glaser, 2012).

In this decade, research universities are seen as sources of commercial technology that is vital to the future of regional economic development, as opposed to institutions that are dedicated to pure scientific discovery alone. There have been attempts to replicate the successes of this new approach to universities, such as Silicon Valley, the Route 128 corridor around Boston (which has it MIT at its core), the Research Triangle Park in North Carolina that has three major universities, as well as Cambridge in the UK. These examples have frequently influenced policy makers who seek to somehow translate the historical developments in these regions to other locales. However, despite many such efforts (Lambooy, 2004), there has been relatively little success to show for this effort (Warren et al., 2008).

Universities in developing countries are not seen as key players in cutting edge innovation or as leaders of industrial commercialization under globalized conditions. While widely acknowledged as important institutions, they primarily func- tion as training sites for knowledge workers and as R\&D sites for redevelopment in technology. Rather than acting as innovators, their potential of generating widely used technological patents or commercialized products has been limited. There is often a mismatch between the ambitious goals of the state and the reality of industry, institutional structure, and market place in these countries (Wu and Zhou, 20I2). Another important factor that has ironically undermined the universities' role is the significant growth of some of the most successful companies. Companies such as Lenovo, Huawei in China and Telmex, CEMEX, GRUMA, Modelo and Bimbo in Mexico have become global companies in their own rights. These companies have a substantial R\&D capacity in their own right and they no longer depend on universities as a source of technology and innovation.

In TT, it is not only the creation of knowledge that counts, but the flow of this knowledge to the company and the aptitude to absorb and transfer this knowledge (Jarohnovich and Avoti $\square$ š, 2009; Feria and Hidalgo, 20 I I). Some researchers have investigated why the inventions from many universities have not been able to produce any meaningful stream of income. First, they have found that high-technology is one of the most difficult things to market. Second, it takes considerable time to successfully license or market good university inventions/patents that often do not make business sense (i.e. cash flow). And third, the university inventor may have no pre-invention/pre-transfer ties to a potential industrial user/licensee; in such cases, marketing of the technology is considerably more challenging because it starts from scratch after the disclosure to the University Office of Technology Transfer (OTT) (Swamidass and Vulasa, 2009).

Mission and environment are another two key drivers of success for the commercialization of technology from universities. The clear establishment of, and broad commitment to, a defined mission statement is critical to the alignment of each component of a university technology transfer strategy. The mission of an OTT should also be defined, or at least supported, at the top levels of the institution's administration. The alignment of OTTs activities with the broader goals of the institution works to justify the investment of resources required to achieve the expected returns (Warren et al., 2008).

The key factors in the TT process include corporate research and development agreements, intellectual property licenses and other agreements.Although this offers intellectual property protection to the technology creator, the high costs of negotiating these agreements make them prohibitively expensive for many emerging entrepreneurial firms. However, these arrangements work well for large firms because large firms have adequate funding. Moreover, large firms are primarily interested in evolutionary technologies that lead 
to rapid market penetration and equally rapid returns on investment in intellectual property agreements. The problem is that independent entrepreneurial firms often focus on disruptive technologies and discontinuous innovations that take much longer to achieve market acceptance and revenue generation (Walsh and Kirchhoff, 2002).

\subsection{Technology transfer models in the world}

A country's competitive advantages increasingly lie in its capabilities to generate further innovations and to effectively use new technology (Choi, 2009). Nevertheless, technology transfer is a complex, difficult process that includes legal issues, technical complexities, financial calculations, and marketing (Lipinski et al., 2008), even when it occurs across different functions within a single product division of a single company. TT is commonly acknowledged to be a complex process that needs time to evolve.

Currently, the topic of TT is wide and dynamic. In addition, concepts of TT encompass many different interpretations and views depending on the organizations' objectives, research background, researchers, developers, users, research areas and disciplines and underlying perspective (Wahab et al., 2009). However, in a simple way the term technology transfer can be defined as the process of movement of technology from one entity to another. Commercial technology transfer may be defined as mutually agreed and goaloriented. The transfer may be said to be successful if the receiving entity (i.e. the transferee) can effectively utilize the technology for business gain. The transfer involves cost and expenditure that should be agreed by the transferee and transferor (Singh and Aggarwal, 20l0).

Considering the difficulties and complexities faced by managers of TT projects, researchers, consultants, and practitioners of technology transfer, since the early 1970s a number of researchers have offered many TT models and methodologies that could facilitate the effective planning and implementation of TT projects. Models help to reduce complex issues and relationships into particular components and to make clear the relationships between them. Consequently, they are not only useful for the description and understanding of complex structures, but they also serve as a starting point for the analysis of correlations (Eckl, 20I2). In particular, a well-developed model of technology transfer could be used as a framework for facilitating a TT process (Choi, 2009). Both qualitative and quantitative models have been proposed in the study of TT.

Qualitative models often have as their objective the delineation of activities involved in managing TT and the elicitation of factors and issues that can influence the success and/ or effectiveness of TT (Ramanathan, 20I I; Singh and Ag- garwal, 2010). On the other hand, quantitative models attempt to quantify significant parameters and then analyze them. These models also try to minimize aim incompatibility between the transferors and transferees in the TT process (Khabiri et al., 20I2).

Detailed historical reviews of qualitative and quantitative TT models have been reported by Ramanathan (201I), Wahab et al., 2009, Sazali et al., 2009 and Singh and Aggarwal (2010). The most cited models in these reports include: appropriability; dissemination; knowledge utilization; communication; Gibson and Simor's model; and the Sung, Gibson, Klein and Lin and Bozeman model. According to Aggrawal (200I), the previous papers in TT can be classified in four categories: firm characteristics (e.g. internal organization and resource allocation), university characteristics (e.g. licensing strategies and incentives for professors to patent), geography in terms of localized spillovers (e.g. relations between universityfirms for TT success) and channels of knowledge transfer (e.g. publications, patents, and consulting) (Agrawal, 200I; Ramanathan, 201 I; Sazali et al., 2009; Singh and Aggarwal, 2010; Wahab et al., 2009).

Recently, a number of new TT models have been proposed by different authors. For example, Warren et al. (2008) reports three models for university TT that are oriented to resolve conflicts between mission and methods, and the dependency on geographic location. Eckl (2012) created an Interactive-Recursive model of knowledge transfer related to generation, diffusion and absorption of external knowledge. Meanwhile, Kim et al. (2009) developed a conceptual model that includes a set of propositions for impacting factors and a proposed process made up of phases that can be used to measure the TT success accurately. Khalozadeh et al. (20II) proposed a TT model based on an efficient university-industry linkage that necessitates the reengineering of educational, research and commercialization processes of university-based research outcomes.

In addition, Trifan et al. (20/2) suggested a model of an innovation center where SMEs (but not exclusively SMEs) are guided to identify and manage their innovation potential, and are supported with valuable know-how in technology transfer from the technical University in Bucharest (Trifan et al., 20I2). Khabiri et al. (20I2) developed a justified technology transfer broadcasting model in which all of the elements are introduced with their relationships in TT within small and medium enterprises. Heinzl et al. (2012) proposed technology transfer models for Austrian higher education institutions that provide valuable insights into the higher education institutions' idiosyncratic factors that affect their TT performance. And finally, Feria and Hidalgo (201 I) developed a science-technological knowledge transfer model in Mexico as a means to boost the limited relations between the scientific and industrial environments. 
These studies have produced contrasting evidence concerning the importance of different types of knowledge outputs of universities to firms. On the one hand, the codified output of academic research (such as publications and patents) seems to be the most important input to industrial innovation (Cohendet and Meyer-Krahmer, 2005). On the other hand, collaborative and contracted research activities appear to be a much more important form of knowledge transfer. Moreover, the employment of university researchers is described as an effective way to transfer knowledge from universities to firms. In addition, informal contacts are often found to be a common form of interaction between universities and industry (Cohendet and MeyerKrahmer, 2005). The form of knowledge flow between university and industry also seems to vary across disciplines (Bekkers and Bodas Freitas, 2008).

The models mentioned above were developed and used to make TT successful. However, a successful transfer of technology is not necessarily guaranteed simply by using a particular model (Choi, 2009).

\subsection{Technology transfer models in Mexico}

In general, previous studies to obtain evidence about TT in Mexico are very limited and mainly focused on topics such as types of knowledge, networks and linkages. The different mechanisms to transfer knowledge or technology are omitted and the few results that there are show the lack of interest from industrial firms in technological R\&D to use TT as a factor in raising their competitiveness (Casalet and Casas, 1998). This evidence indicates that there is an important weakness in the analysis of the TT processes between scientific and industrial environments (Feria and Hidalgo, 20I I).

In the National Innovation System of Mexico, it is possible to identify a gap between the generation, transformation and application of knowledge. In general, the line followed by most of the research centers and universities has been to provide human resources to firms, acting like a spectator of industrial and economic development of the country (Feria and Hidalgo, 20I I).

One of the reasons why TT is limited in Mexico is that Mexican researchers in universities or research centers are responding to the incentives created by the National System of Researchers (SNI, based on the name in Spanish) and by the National Council of Science and Technology (CONACYT), which encourages researchers to continue publishing throughout their lives but does not encourage them to obtain patents or transfer their inventions. Although researchers in Mexico typically have tenure in their respective institutions, their base salary is about one-third of what they can actually receive. The other two-thirds are given in the form of pecuniary compensations directly from $\mathrm{SNI}$ and from the university where the researchers work; they are also a function of SNI's appraisal of the candidate's proficiency. Moreover, SNI is based on current performance and does not guarantee any type of "tenure". In addition, its payments are not considered as a salary when establishing a person's retirement pension. Therefore, researchers are reluctant to retire and they have to continue publishing some papers in order to receive these salary complements, which works against activities oriented to generate TT. Mexican researchers can choose between allocating time to publishing, to patenting, or to teaching. Perhaps these activities complement each other, but if not then the current reward system may be giving fewer incentives to those activities that produce a higher social payoff (Gonzalez-Brambila and Veloso, 2007).

In recent years, Feria and Hidalgo (20II) from the Department of Business Administration of the Universidad Politécnica de Madrid reported a science-technological knowledge transfer model in Mexico as a means to boost the limited relations between the scientific and industrial environments. This proposal is unique in Mexico and is based on the analysis of eight organizations (four research centers and four Mexican firms), which have varying degrees of skill in the practice of science technological knowledge transfer. Feria's (20II) study used a case study approach. His analysis highlights the synergistic use of the organizational and technological capabilities of each organization as a means to identify the knowledge transfer mechanisms that are best suited to enabling the establishment of cooperative processes and to achieve results in R\&D and innovation activities. Feria and Hidalgo (20I I) concludes that the results of the application of his model reveals the need to improve the TT and cooperative processes in relation to the science and technology (S\&T) activities developed by these organizations. At the level of cooperative relations, it is noted that most of these organizations make use of all available mechanisms. However, the intensity with which they are applied varies greatly between the mechanisms and among similar organizations. Although all of these institutions have developed their R\&D and innovation activities at different degrees of intensity, the analysis showed several weaknesses with respect to the form to transfer and the absorption of the S\&T results.

\subsection{The role of the networks in the TT process}

Networks seem to be typical of the present time. Examples of modern networks include globalization, turbulent environments, swift changes of technology, innovation, and the rise of the Internet. In general, it can be contended that networks fulfill two functions: the first is facilitating the co-ordination of decisions made by separate entities (or 'nodes') of the network (such as persons, departments, firms, and cities); and the second is the transmission of data, informa- 
tion, and knowledge by using or making 'connections' with various degrees of intensity.

It can be argued that 'embedded dynamic relations' are extremely important to the development and transmission of knowledge, technology, and innovations. In a process of selforganization, entrepreneurs and scientists attempt to establish network structures in order to enhance the spread of information. In many cases, these relations need trust and embeddedness in order to benefit from the available capacities of the various persons involved in the process. Markets as well as networks and institutions need to be developed in order to contribute to the effectiveness of regional innovation systems (Lambooy, 2004).

Prato and Nepelski (2012) studied the structure and evolution of global technological collaboration networks and they created a unique map of technological collaborations between countries around the world (i.e. the global technological collaboration network). They then analyzed the determinants of the formation of technological collaboration relationships between countries. They began by examining the structure and dynamics of: the global technological network, the workings of network interactions, what positions the countries occupy, and how economic fundamentals affect the formation of technological networks.

Open innovation networks (e.g. Yeti.com, Inno Centive, TelScout) connect industry, academic institutions, and public and non-profit organizations with a global network of research scientists to manage intellectual property and provide innovative solutions to a challenging problem (Heinzl et al., 20I2). Innovations and their commercialization are based on networking effects between the academic researchers and industry. The OTT serves as the hub of the university-industry links, and it enables researchers to engage in networking activities (Krücken et al., 2007).

In Mexico, CONACYT runs the Research Thematic Networks in 2006 with the purpose of making connections between scientists, technologists and entrepreneurs to address research strategic areas. In 20 I I, 20 Research Thematic Networks were integrated, 18 of which were in operation. In 20I I, CONACYT published a call to enroll researchers and institutions in their thematic networks; as result of this call the associated members of the networks increased to 3,494 individuals and 132 institutions. The knowledge areas of these networks include: water; mathematical and computational models; the bar code of life; ecosystems; complexity, science and society; poverty and urban development; the physics of high energies; the Mexican network of soft condensed matter; energy sources; ageing, health and social development; environment and sustainability; robotics and mechatronics; nanosciences and nanotechnology; hydro me- teorological and climate disasters; new trends in medicine; ethnoecology and biocultural heritage; foods, agriculture and biotechnology; scientific research and space technology; information technologies; and, civil society and quality of democracy (CONACYT-SIICYT 20II).

In 2006, the Instituto Politecnico Nacional (IPN), which is one of the three largest public Universities in Mexico (the other two are Universidad Nacional Autonoma de Mexico and Universidad Autonoma Metropolitana), created their own researchers networks with the objective of fostering investigation and making connections between researchers and firms in order to address national problems. Currently, the Politecnico research networks have I,050 members associated in the following nine networks: biotechnology, nanosciences, environment, computation, energy, economic development, health, telecommunications, and robotics and mechatronics (Villa, 2002).

Both CONACYT and IPN researchers networks has been fostering linkages with Mexican firms and organizations in order to implement research projects that are oriented to solve the most demanding present problems in these firms and organizations. The main outcomes of these networks include research projects, patents, technology transfers, and annual meetings with personnel from firms and organization.

\section{Research Aim}

The overall aim of this study is to develop a model of TT describing the importance of the researcher-firm networks for public Universities in Mexico. The research objectives of this study are listed as below:

Research Objective I: Identify of factors influencing the technology transfer performance for Mexican public universities. Research Objective 2: Conduct a review of two recent technology transfer models that are used as basic concepts for developing a model of technology transfer.

Research Objective 3: Develop a technology transfer model for the public universities in Mexico based on researcherfirm networks.

\section{Research Methodology}

This study is based on a review of two recent technology transfer models that are used as basic concepts for developing our own model of technology transfer. The two models with their weakness are completely reviewed. A justified conceptual model is then introduced, which is based on researcher-firm networks. The first TT model revised is the Scientific-Technological Knowledge Transfer Model, which was developed by Feria and Hidalgo (20II) and proposed 
specifically for Mexico; the second TT model was developed for Austrian higher education institutions by Heinzl et al. (20I2). Both models and model types will be outlined briefly below to subsequently develop our own model through criticism, merging, and modification of the two types.

\section{Conceptual Model of TT for Mexican Public Uni- versities based on Researcher-Firm Networks}

\section{I Feria's Scientific-Technological KnowledgeTrans- fer Model}

Feria's model (see figure I) is based on the fact that those organizations that have succeeded in TT processes have many distinctive features that facilitate or hinder these processes. The establishment of TT agreements is usually the result of the synergistic combination of many aspects, including: organizational profile (i.e. organizational characteristics and management system); technological profile (i.e. R\&D and innovation activities, information sources, management techniques, and technology management models); knowledge transfer profile (i.e. mechanisms, links with other organizations and structures to support knowledge transfer); and motivations (i.e. impacts-benefits and obstacles). This model shows the relationships of influence between these profiles, aiming to develop a knowledge of the transfer process.

Therefore, the model responds to the question of how to align the internal R\&D and innovation activities in the analyzed organizations to the knowledge transfer processes that are developed with other organizations. Some aspects were not considered in the Scientific-Technological Knowledge Transfer model for use in Mexican universities. For instance, the model was proposed to analyze only research centers in Mexico without including universities. The main researcher force in Mexico is concentrated in public universities ( $60 \%$ vs $10 \%$ in research centers) (CONACYT-SIICYT 20II). Meanwhile, the firms selected for the study are not representative of industry in Mexico; for example, the innovation systems of Mabe and Silanes have been recognized as among the best in the country. In addition, in Mexico basic needs are not resolved in TT; this problem is related to communication strategies, generating incentives, better regulation, and increased certainty in intellectual property (Cabrero et al., 20l I). Finally, Feria's model does not consider the fact that researchers in universities or research centers are still responding to the incentives created by the National System of Researchers.

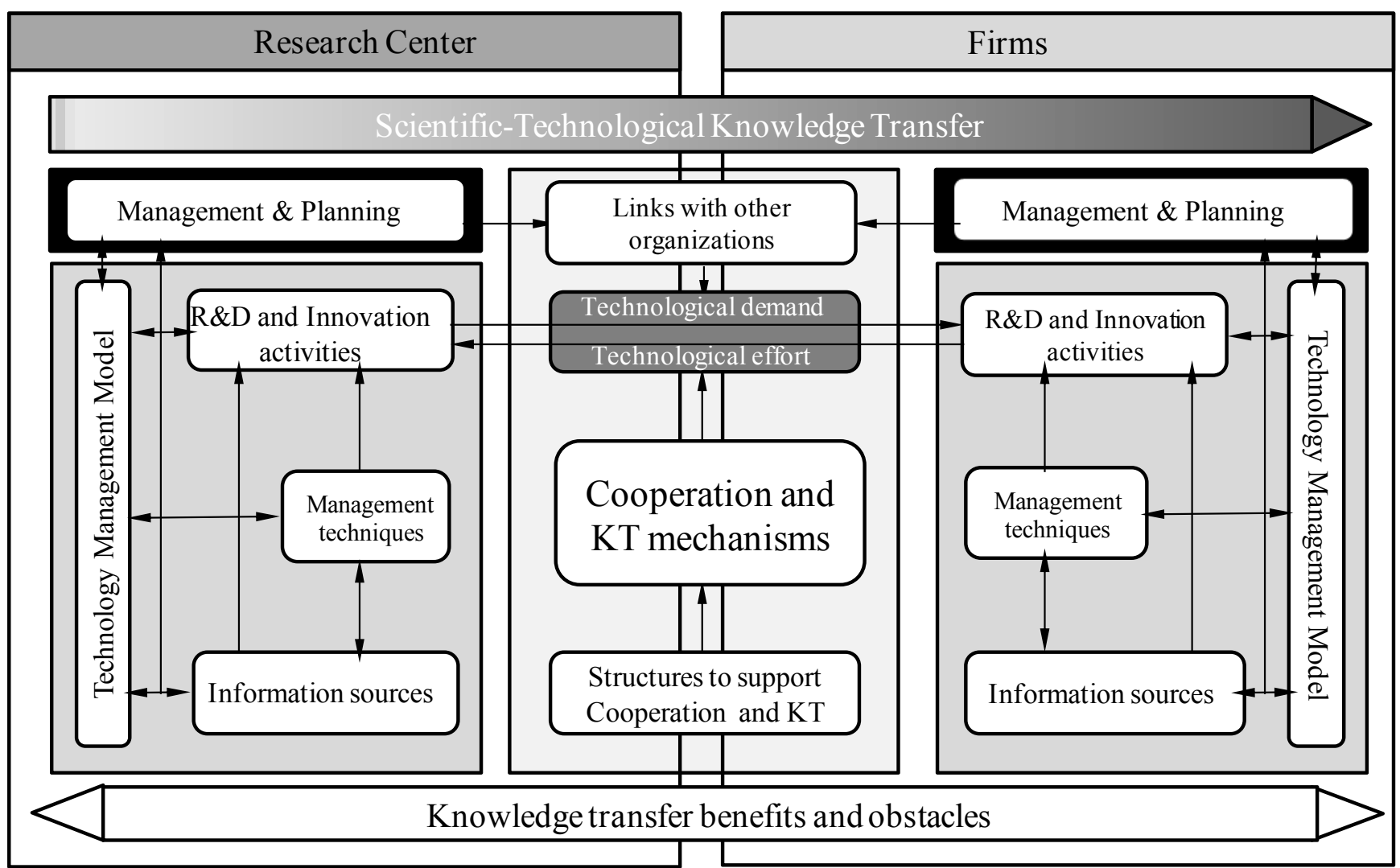

Organizational profile Technological profile $\square$ Knowledge transfer profile Motivations

Figure I Scientific-Technological Knowledge Transfer Model. Source: (Feria and Hidalgo, 20 I I).

ISSN: 07 I8-2724. (http://www.jotmi.org)

Journal of Technology Management \& Innovation @ Universidad Alberto Hurtado, Facultad de Economía y Negocios. 


\subsection{Technology transfer model for Austrian higher education institutions}

The factors influencing technology transfer performance of the technology transfer model that was proposed by Heinzl et al., 2012 are coded into three categories, namely: providing agent related factors; receiving agent-related factors; and, environment- and transaction-related factors (Table I). The first category concerns institutions that provide the technology, while the second concerns those institutions that are at the receiving end. The third category involves the environment they are in as well as the interface between them. Heinzl (2012) concludes from his model that it is necessary to: create strategic partnerships with other institutions in the science base through research networks; establish con- sortia to build a better research image; increase research funding; effect research structural changes relating to research staff, groups, and centers; and exploit the services of intermediary institutions (e.g. regional development agencies, patent offices, and funding consultancy agencies).

This model was developed based on the Austrian universities use of an applied sciences context, and as such it cannot be applied directly to other countries; however, some elements from this model can be considered for a TT model for use in public universities in Mexico. First, this model has provided valuable insights into the idiosyncratic factors of higher education institutions that affect their technology transfer performance. Second, it creates strategic partnerships with other institutions in the science base through re-

\begin{tabular}{|c|c|c|}
\hline Categories & $\begin{array}{l}\text { Factors affecting technology transfer } \\
\text { performance }\end{array}$ & Key dimensions \\
\hline \multirow[t]{4}{*}{ Providing agent-related factors } & Mission and strategy & $\begin{array}{l}\text { R\&D thematic focus } \\
\text { R\&D orientation } \\
\text { Research mission }\end{array}$ \\
\hline & Infrastructure and resources & $\begin{array}{l}\text { Financial resources } \\
\text { Technical infrastructure } \\
\text { Size of R\&D team }\end{array}$ \\
\hline & $\begin{array}{l}\text { Scientific and technological (S\&T) } \\
\text { human capital }\end{array}$ & $\begin{array}{l}\text { Scientific excellence } \\
\text { Application awareness } \\
\text { Business excellence } \\
\text { Personal networks } \\
\text { Motivation }\end{array}$ \\
\hline & Research organizational design & $\begin{array}{l}\text { Research organizational } \\
\text { structure } \\
\text { Processes } \\
\text { Support structures } \\
\text { Incentive schemes } \\
\text { R\&D image }\end{array}$ \\
\hline \multirow[t]{2}{*}{ Receiving agent-related factors } & Industrial demand & $\begin{array}{l}\text { Articulated demand } \\
\text { Latent demand }\end{array}$ \\
\hline & Utilization capability & $\begin{array}{l}\text { Absorptive capacity } \\
\text { Commercialization } \\
\text { capability }\end{array}$ \\
\hline \multirow[t]{2}{*}{$\begin{array}{l}\text { Environment and transaction related } \\
\text { factors }\end{array}$} & Transaction modalities & $\begin{array}{l}\text { Transfer conditions } \\
\text { Transfer mechanisms } \\
\text { Supply-demand-matching } \\
\text { Confidentiality } \\
\text { Social cohesion }\end{array}$ \\
\hline & Framework conditions & $\begin{array}{l}\text { Funding programs } \\
\text { Intermediary structures } \\
\text { Regulation \& legislation } \\
\text { Collaboration culture }\end{array}$ \\
\hline
\end{tabular}

Table I. Generic technology transfer model. Source: (Heinzl et al., 20I2)

ISSN: 07 I 8-2724. (http://www.jotmi.org)

Journal of Technology Management \& Innovation @ Universidad Alberto Hurtado, Facultad de Economía y Negocios. 
search networks. Third, in many universities technological innovations have not been fully commercially exploited owing to significant financial and managerial resources constraints, as well as a lack of an appropriate support infrastructure. And fourth, the technological innovation commercialization ecosystem aims to provide an appropriate infrastructure and a stimulating environment to transfer a university technology to the market.

It is evident from the review above that policies for regional development need to be tailored much more specifically, a one size fits all approach is not appropriate when building an effective TT process. In addition, TT models have to be structured taking into account national circumstances, sector, technology type, the local resources, organizational culture of TT, researchers reward system, channels of interaction, infrastructure, and social limitations. Figure 2 illustrates the justified technology transfer model. This model is regarded as an improvement over the two previous models for its application in Mexican public universities and for its greater emphasis on researcher-firm networks.
The interactive model of knowledge transfer depicted is made possible through the establishment of three basic dimensions and the connection of each dimension with a group of actors that represent the variables of the model. The factors influencing technology transfer performance are coded into three categories, namely providing agent related factors, receiving agent-related factors, and environmentand transaction-related factors. The first category concerns institutions that provide the technology. The second category concerns the institutions that are at the receiving end. Meanwhile, the third category involves the government who acts as the interface between the two.

The relations presented in the model are intended to take advantage of the university and CONACYT networks results and they aim to fill the gaps found in the TT Mexican processes. A key element in the model is the incentives created by the National System of Researchers for Mexican researchers in the universities or research centers, which is considered to be an important variable that will encourage researchers to develop and transfer technology as well as

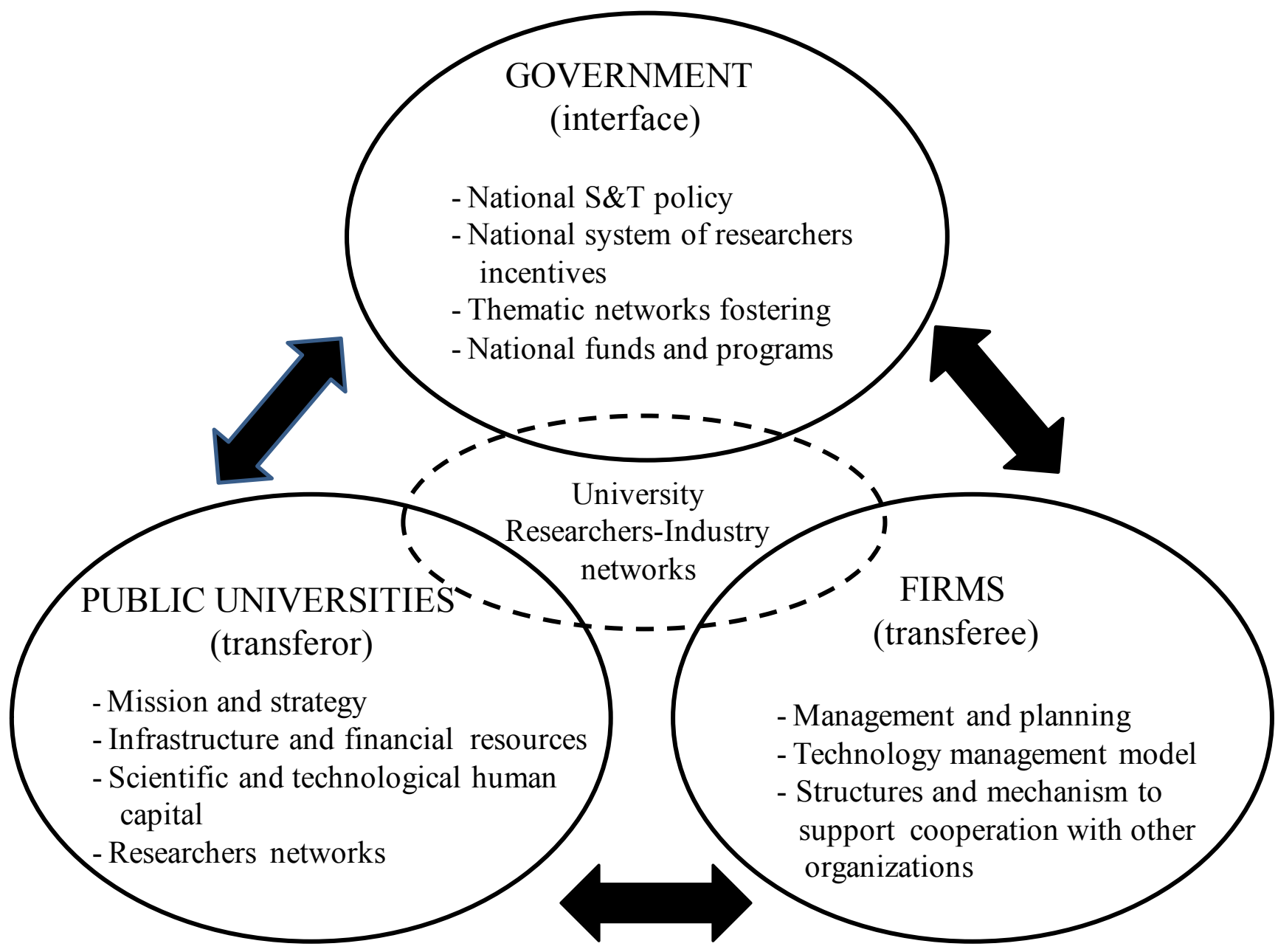

Figure 2:Technology transfer model for Mexican universities based on university researcher-industry networks. Source: Own elaboration

ISSN: 07 I8-2724. (http://www.jotmi.org) 
aiding publishing. This sort of university-firm-government interaction based on networks that is suggested in our model has been in operation in Spain since 1997. The Spanish network, which is called the Foundations of Business University (REDFUE), was created as an association whose members work to promote relations between the three sectors. At present, REDFUE University Foundations integrates 31 companies and it has a presence in 17 regions (Barcena, 2010). However, a successful transfer of technology might not be guaranteed simply by using a particular model. Collaborative and contracted research activities have to be considered as an additional and important form of knowledge transfer. Moreover, the employment of university researchers has to be used as an effective way to foster transfer knowledge from universities to firms.

Mexico is not yet a knowledge-based economy. There are two challenges to establishing this knowledge-based economy. The first is to effectively create technology transfer channels for converting the country's research capacity and human capital into an asset for economic growth, competitiveness, and rising standards of living. The second is enhancing competitiveness and productivity in low and mediumtech sectors. The conceptual model proposed by this study could be useful to improve the efficiency of existing technology transfer mechanisms. It may also be used to motivate enterprises towards innovation. It can also increase industry's awareness of technological needs and improve the accessibility of research institutions and their products.

\section{Conclusions}

Universities have their own (sometimes unlike) goals and missions, research environments and organizational structures. Consequently, every university has a different understanding and anticipation from the results of a successful technology transfer. Mexican public universities must consider providing greater rewards for faculty involvement in technology transfer, which will generate more licenses and royalty income, and foster the research of research networks. It will also allow national leadership in TT to develop and create an entrepreneurial climate that will generate more licenses.

Finally, it can be said that this new model has overcome some of the disadvantages of the two previous models in the Mexican S\&T context. Therefore, this paper has developed a technology transfer model that takes the current situation of S\&T in Mexico into consideration. It also takes into account the system of incentives received by Mexican researchers.

In further study, it would be useful to test the propositions we have outlined in our model. A first step would be to conduct a comprehensive survey of researchers, firms and CONACYT in order to measure the variables in our model.

\section{References}

AUDRETSCH, D. B., Lehmann, E. E., \& Wright, M. (20I2). Technology transfer in a global economy. The Journal of Technology Transfer, I- I2, doi: I0.1007/s 1096 I-0 I 2-9283-6.

BARCENA, A. (20I0). Espacios iberoamericanos: vínculos entre universidades y empresas para el desarrollo tecnológico: Comisión Económica para América Latina y el Caribe (CEPAL) / Secretaría General Iberoamericana.

BEKKERS, R., \& Bodas Freitas, I. M. (2008). Analysing knowledge transfer channels between universities and industry: To what degree do sectors also matter? Research Policy, 37(10), 1837-1853, doi:http://dx.doi.org/10.1016/j.respol.2008.07.007.

BREZNITZ, S. M., \& Feldman, M. P. (20I2). The larger role of the university in economic development: introduction to the special issue. The Journal of Technology Transfer, 37(2), I35|38, doi:10.1007/s |096|-010-9|84-5.

CABRERO, E., Cárdenas, S.,Arellano, D., \& Ramírez, E. (20I I). La vinculación entre la universidad y la industria en México. Una revisión a los hallazgos de la Encuesta Nacional de Vinculación. Perfiles Educativos, 33, 86-199.

CASALET, M., \& Casas, R. (1998). Un diagnóstico sobre la vinculación universidad-empresa, CONACYT-ANUIES:Asociación Nacional de Universidades e Instituciones de Educación Superior, Dirección de Servicios Editoriales y Consejo Nacional de Ciencia y Tecnología.

COHENDET, P., \& Meyer-Krahmer, F. (2005). Technology Policy in the Knowledge-Based Economy. In P. Llerena, \& M. Matt (Eds.), Innovation Policy in a Knowledge-Based Economy (pp. 75-I 12): Springer Berlin Heidelberg.

CONACYT-SIICYT (20II). Informe de Labores. Consejo Nacional de Ciencia y Tecnología.

CHOI, H. J. (2009). Technology Transfer Issues and a New Technology Transfer Model. The Journal of Technology Studies, 35, 49-57.

ECKL,V. C. (20I2). Creating an Interactive-Recursive Model of Knowledge Transfer. CBS, Copenhagen, Denmark,

FERIA, V., \& Hidalgo, A. Towards a transfer model of scientific and technological knowledge: The case of Mexico. In, 2011 (pp. I-19): International Association for Management of Technology

ISSN: 07 I8-2724. (http://www.jotmi.org)

Journal of Technology Management \& Innovation @ Universidad Alberto Hurtado, Facultad de Economía y Negocios. 
GOLDSTEIN, H. A., \& Glaser, K. (20/2). Research universities as actors in the governance of local and regional development. The Journal of Technology Transfer, 37(2), I58-174, doi:I0.1007/s |096|-010-9193-4.

GONZALEZ-BRAMBILA, C., \& Veloso, F. M. (2007). The determinants of research output and impact: $A$ study of Mexican researchers. Research Policy, 36(7), 1035-105I, doi:10.1016/j.respol.2007.03.005.

HEINZL, J., Kor, A. L., Orange, G., \& Kaufmann, H. (20I2). Technology transfer model for Austrian higher education institutions. The Journal of Technology Transfer, I-34, doi:I0.1007/s 1096I-012-9258-7.

HEISEY, P., \& Adelman, S. (20II). Research expenditures, technology transfer activity, and university licensing revenue. The Journal of Technology Transfer, 36(I), 38-60, doi: I0.1007/ sl0961-009-9|29-z.

JAROHNOVICH, N., \& Avotinšs, V. (2009). Assessment of technology transfer and difussion models in Latvia. Journal of Business Management, 3I-4I.

KHABIRI, N., Rast, S., \& Senin,A.A. (20I2). Identifying Main Influential Elements in Technology Transfer Process:A Conceptual Model. Procedia - Social and Behavioral Sciences, 40(0), 4I7-423, doi:http://dx.doi.org//0.1016/j.sbspro.2012.03.209.

KRÜCKEN, G., Meier, F., \& Müller, A. (2007). Information, cooperation, and the blurring of boundaries - technology transfer in German and American discourses. Higher Education, 53(6), 675-696, doi:10.1007/s 10734-004-7650-4.

LAMBOOY,J. (2004).The transmission of knowledge, emerging networks, and the role of universities: An evolutionary approach. European Planning Studies, 12(5), 643-657, doi: 10. 1080/0965431042000219996.

LIPINSKI, J., Minutolo, M. C., \& Crothers, L. M. (2008). The Complex Relationship Driving Technology Transfer:The Potential Opportunities Missed by Universities. Institute of Behavioral and Applied Management, I I 2-I33.

PRATO, G., \& Nepelski, D. (20I2). Global technological collaboration network: network analysis of international co-inventions. The Journal of Technology Transfer, I-I8, doi:I0.1007/s |096|-0|2-9285-4.

ROLFO, S., \& Finardi, U. (20I2). University Third mission in Italy: organization, faculty attitude and academic specialization. The Journal of Technology Transfer, I-I5, doi:10.1007/ sl096I-0I 2-9284-5.
SAZALI, A.W., Haslinda, A., Jegak, U., \& Raduan, C. R. (2009). Evolution and development of technology transfer models and the influence of knowledge-based view and organizational learning on technology transfer. Research Journal of Internatıonal Studies(I2), 79-9I.

SIEGEL, D., \& van Pottelsberghe de la Potterie, B. (2003). Symposium Overview: Economic and Managerial Implications of University Technology Transfer (Selected Papers on University Technology Transfer from the Applied Econometrics Association Conference on "Innovations and Intellectual Property: Economic and Managerial Perspectives"). The Journal of Technology Transfer, 28(I), 5-8, doi:10.1023/A:10216208I7749.

SIEGEL, D. S., Waldman, D., \& Link, A. (2003). Assessing the impact of organizational practices on the relative productivity of university technology transfer offices: an exploratory study. Research Policy, 32(I), 27-48, doi:http://dx.doi. org/I0.1016/S0048-7333(01)00196-2.

SIEGEL, D. S., Waldman, D. A., Atwater, L. E., \& Link, A. N. (2004). Toward a model of the effective transfer of scientific knowledge from academicians to practitioners: qualitative evidence from the commercialization of university technologies. Journal of Engineering and Technology Management, $2 I(I-2)$, II5-I42, doi:http://dx.doi.org//0.10I6/j.jengtecman.2003.12.006.

SINGH,A., \& Aggarwal, G. (20I0). Technology Transfer Introduction, Facts and Models. International Journal Of Pharma World Research, I (2), I-8.

SWAMIDASS, P. M., \& Vulasa,V. (2009). Why university inventions rarely produce income? Bottlenecks in university technology transfer. The Journal of Technology Transfer, 34(4), 343-363, doi: I0.1007/s I096I-008-9097-8.

TRIFAN, E.-L., Guică, R.-I., \& Micu, C.-A. (20I2). Innovation management and technology transfer within a model of innovation center at the University Politechnica of Bucharest. Problems of management in the 2 Ist century, 4, 75-85.

VILLA, R. E. (2002). La Investigación y el Posgrado en la Estrategia General para la Implantacion del Nuevo Modelo Educativo y del Modelo de Integración Social (Vol. 18). Mexico City: IPN.

WAHAB, S.A., Rose, R. C., Uli, J., \& Abdullah, H. (2009).A Review on the Technology Transfer Models, Knowledge-Based and Organizational Learning Models on Technology Transfer. European Journal of Social Sciences, 10(4). 
WALSH, S. T., \& Kirchhoff, B. A. (2002). Technology transfer from government labs to entrepreneurs. Journal of Enterprising Culture, 10(02), 133-149, doi:doi:10.1142/ S02I8495802000I77.

WARREN, A., Hanke, R., \& Trotzer, D. (2008). Models for university technology transfer: resolving conflicts between mission and methods and the dependency on geographic location. Cambridge Journal of Regions, Economy and Society, I (2), 219-232, doi:I0. I093/cjres/rsm009.

WU, W., \& Zhou, Y. (20I2). The third mission stalled? Universities in China's technological progress. The Journal of Technology Transfer, 37(6), 812-827, doi:10.1007/s109610II-9233-8. 